\title{
Books in Review / Comptes rendus
}

\author{
Michel Brisebois and/et François Melançon
}

Ernie Ingles, ed. and comp., and Gordon R. Adshead, principal researcher and comp. Bibliography of Canadian Bibliographies / Bibliographie des bibliographies canadiennes. 3 rd ed. Toronto: University of Toronto Press, 1994. xliii, [5], I 178 pp.; \$150.00 (cloth). ISBN 0-8020-2837-3.

A new edition of Douglas Lochhead's 1972 Bibliography of Canadian Bibliographies/Bibliographie des bibliographies canadiennes had been discussed since I977 when Douglas Lochhead and Peter E. Greig suggested major changes for a third edition in a paper prepared for the Bibliographical Society of Canada. In 1988 the National Library of Canada's Committee on Bibliography and Information Services for the Social Sciences and Humanities prepared a feasibility study for the project. Initial funding was obtained from the Social Sciences and Humanities Research Council of Canada's Canadian Studies Research Tools Program, and the project, launched in 1989 with Ernie Ingles as chief editor and compiler and Gordon R. Adshead acting as principal researcher and compiler, drew to a close in mid-1993. The final product, published in December 1994 by the University of Toronto Press, is a superb reference tool, and an outstanding model of bibliographical practice - well worth a twenty-two year wait.

This third edition of the Bibliography of Canadian Bibliographies/Bibliographie des bibliographies canadiennes, cited hereafter as $B C B: 3$, enlarges, updates and revises the previous edition - excluding entries from the earlier edition which did not fit the new inclusion criteria, and adding items that had been omitted from the previous editions, as well as those eligible titles published in the intervening years. It covers a time frame from 1789 to mid-1993 and contains ' 7,375 entries, representing over 10,000 editions and supplements' with at least $75 \%$ of the entries published after 1973 .

Eligibility criteria were tightened for this new edition, and a great many titles from the second edition were excised during the process of revision. Canadian bibliographies have now been defined as those 'relating in subject to Canada' excluding any which, while published in Canada or of Canadian authorship, have a foreign subject matter - 'i.e. which do not further our understanding of things, people or events Canadian, or Canada's place in the world.' This change in policy is at variance with the much broader definition of 'Canadiana' as outlined by the National Library in its national bibliography. It does, however, reflect the boundaries of the discipline of Canadian Studies as defined in the 1975 report of the 
Commission on Canadian Studies, To Know Ourselves. The resulting list is a far more useful reference tool for students and scholars of Canada.

Among the categories of material excluded from the $B C B: 3$ - such as citations for unpublished manuscript bibliographies, primarily those produced by library school students (although 'bibliographies produced as thesis' are included); bibliographies appended to monographs, theses, or articles in serials; and general library catalogues and accession lists - are electronic formats and databases. The exclusion of this category will disappoint many researchers, given the growing importance of this medium, with electronic formats often superseding print sources. The National Library's Canadian Translations/Traductions canadiennes (\#I 493), for example, is now available only as a computer file. Certainly, any subsequent editions or supplements to the $B C B$ should include electronic formats and databases.

One important criterion for inclusion was that every item listed was 'examined and a known location has been included in each entry' so that each 'was accessible to the general public, either by way of in-person examination or through the interlibrary loan network.' Very few entries deviate from this ideal, although at least one (\#5705) lacks a location field, while a few others (e.g. \#3253 and \#44I7) are attributed to the National Library (OONL) while not appearing as National Library holdings on DOBIs, its on-line union catalogue. Nevertheless, these few anomalies are just that, and the attention to detail and careful editing are to be commended.

The organization of the bibliography is by subject-class, modified to suit the exigencies of the project - General/Canada; Area Bibliographies; Arts and Humanities; Social Sciences; Sciences and Applied Sciences; Types of Materials (Serials, Newspapers, Theses, Official Publications, Maps, Audio-visual Materials); Catalogues/Collections and Individuals. Finer subject divisions within the broad classes (e.g. within Art and Humanities are Arts and Design, Architecture, Music, Performing Arts, Literature, Children's Literature, Linguistics and Translation, Religion and Philosophy, Library/Information Science/Publishing, Sports and Recreation) are further subdivided by date of publication. The bibliography, thus organized, is extremely easy to use and enables researchers to search for publications covering specific topics and time periods. In addition researchers 'are provided with some sense of the evolving disciplinary/bibliographic inventory the latter intended to guide bibliographers in identifying lacunae within the Canadian bibliographical record.'

A short entry listing (bibliographical description without the note field) by straight alphabetical arrangement provides quick and easy access for specific items one wishes to locate - a feature which this reviewer has used to advantage on more than one occasion.

Access is further enhanced through a number of indexes - an author index for personal and corporate authors as well as the compilers, editors, etc. whose names appear in the notes; a title index which also includes titles found within the note field; and a subject index (both English and French) based on terms taken from the Canadian Thesaurus: A Guide to the Subject Headings Used in the Canadian Periodical Index and CPI Online. The over 50,000 additional access points ensure 
researchers will be able to find bibliographical tools quickly and easily. The volume thus manages to combine the flexibility of a database with the convenience of a printed text.

The entries follow the guidelines of the Bibliographic Style Manual/Guide de rédaction bibliographique, by Danielle Thibault (Ottawa: National Library of Canada, I 989 |, and the introduction clearly explains the format through a number of sample entries. The records themselves are easy to read, with main entry and note field headings in bold. The note area of each record is particularly useful, supplying information such as number of entries in the bibliography; period of coverage; brief descriptors of subjects covered; previous editions or supplements; and whether the bibliography has been produced on microform.

The bilingual features of the bibliography include a table of contents, introductory material, headers, and subject indexes in both English and French. Notes for documents in English and French appear in the language of publication, or in the case of bilingual documents, in the language of the first title. Documents in 'têtebêche' or 'tumble' format have two entries, one in either language. Notes for documents in languages other than English or French appear in English.

The breadth and depth of coverage are impressive, as evidenced by the list of 396 serial titles examined for references. Entries range from Canadiana: Canada's National Bibliography (\#or 84) to a bibliography of Canadian Studies in Japan, Kanada kankei hogo bunken mokuroku: 1977-1988 (\#016I).

A check of a number of titles does reveal some lacunae. For example, the Inventaire des sujets de thèses déposées et soutenues depuis 1970 dans les Universités françaises concernant le Canada which appeared in 1979 as number 7 of Études canadiennes/Canadian Studies is not listed in the BCB:3, although Études canadiannes/Canadian Studies is one of the titles in 'Serial Titles Searched' at the end of the volume. Robert Denham's ongoing bibliography of Northrop Frye, which appears in his Northrop Frye Newsletter is not mentioned, nor is the ongoing checklist of current works by and about Margaret Atwood which appears annually in the Newsletter of the Margaret Atwood Society. And it is unfortunate that the note area of the 'ongoing' annual Peace and Security Bookshelf $(\# 2555)$ and its French version La bibliothèque paix et sécurité (\#2556) does not identify the new organization responsible for the publication since the 1992 demise of the Canadian Institute for International Peace and Security.

The above noted examples serve only to illustrate the obvious - that no enumerative bibliography of current materials is or ever can be complete, despite the best intentions and the most rigorous research. As the editor himself acknowledges, the $B C B$ is a 'work in progress,' and 'the search for relevant bibliographies has not ended with the publication of this volume.' Readers are encouraged to provide notices of additional items, and this bibliography will, we hope, spur others to review the areas of their own expertise, exchanging information with the editor and furthering the goals of this 'work in progress.' What is noticeably lacking in the bibliography is not any particular title, but reference to a proposed publication schedule for supplements, new editions, or on-line access. We look forward to any such announcements, all the while unreservedly recommending 
the bibliography as an essential volume for libraries and the students and scholars of Canada worldwide.

LINDA M. JONES

International Council for Canadian Studies

Mark C. Bartlett, Fiona A. Black, and Bertrum H. MacDonald. The History of the Book in Canada: A Bibliography. Halifax: B.H. MacDonald, 1993. xi, [I], 260 pp.; $\$ 25.00$ (spiral bound). ISBN O9697349-0-5.

Antiquarian booksellers purchase more bibliographies per capita than any other group in society. The reason, of course, is that our livelihood depends on having complete, useful, and accurate reference works to assist us in identifying and selling the books in our stock. Our minor triumphs occur when we can describe a book as 'not in Tremaine,' 'not in Fleming,' or 'not in Winearls.' For this reason I had no hesitation in mailing my cheque to buy this study of the history of the book in Canada, compiled by Mark Bartlett (Head of Technical Services, Technical University of Nova Scotia), Fiona Black (Librarian with Regina Public Library) and Bertrum MacDonald (Associate Professor, School of Library and Information Science, Dalhousie University).

In the introduction, which uses the phrase 'a half millenia since Gutenberg,' the compilers announce plans for a second edition. I await the second edition eagerly, for the physical appearance and careless editing of this first edition are an embarrassment both to the bibliographical community in Canada and to one of our oldest universities. The compilers state 'we readily acknowledge weaknesses' and 'sources of information that we used are either incomplete or laden with errors.' This disclaimer is no excuse for rushing into print laden with more errors and demonstrably incomplete.

From the table of contents and the awkwardly written introduction, the reader learns that 'this Bibliography is designed to fill a need for a reference in this growing field and it should reduce some of the frustrations for searchers. . . ' (p. v). The approximately 1,500 titles are grouped into main and secondary categories totalling 2,04I entries. Analysis of the I,755 main entries shows a heavy preponderance devoted to libraries and librarianship as follows (with number of entries in each): General (3 I); Paper, Ink, Type Design, and Type-Founding (53); Printed Books and Printing (237); Illustration (7I); Bookbinding and the Book Arts (9); Book Trade and Publishing (3 I I); Bibliophily and Book Collecting (75); Institutions, Libraries, and Librarianship (4I8); Legal and Economic Aspects (7I); Social Aspects (I 86); and Periodicals, Newspapers and Journalism (293). The paucity of entries on bookbinding and the book arts reveals not one for the Canadian Bookbinders and Book Artists Guild with its outstanding newsletter and superb travelling exhibition catalogues. The four indexes occupy seventy pages. The author/editor, title, and topical name indexes are quite useful, except for many 